\title{
Enhancement of Cycle Performance of Lithium Secondary Batteries Based on Nano-Composite Coated PVdF Membrane
}

\author{
Myung-Hyun Ryou, Young-Dal Han, Je-Nam Lee, Dong-Jin Lee, and Jung-Ki Park* \\ Department of Chemical and Biomolecular Engineering, Korea Advanced Institute of Science \\ and Technology, 373-1, Guseong-dong, Yuseong-gu, Daejeon 305-701, Republic of Korea
}

(Received August 21, 2008 : Accepted August 25, 2008)

\begin{abstract}
The multilayered membrane for lithium rechargeable batteries based on poly (vinylidene fluoride) (PVdF) is prepared with the coated layer containing nano-sized filler. The prepared membranes were subjected to studies of mechanical strength, morphology, interfacial stability, impedance spectroscopy, ionic conductivity, and cycle performance. The localized inorganic filler in the PVdF composite membrane rendered mechanical strength much reduced because of its low stretching ratio and it results in around half value of the mechanical strength of highly stretched PVdF membrane. In order to achieve high ionic conductivity and interfacial stability without sacrificing high mechanical strength, coating layer with nano-filler was newly introduced to $\mathrm{PVdF}$ membrane. The ionic conductivity of the coated membrane was $1.03 \mathrm{mS} / \mathrm{cm}$, and the interface between the coating layer and PVdF membrane was stable when the membrane was immersed into liquid electrolyte. The discharge capacity of the cell based on nano-filler coated PVdF membrane was around $91 \%$ of the initial discharge capacity after 250 cycles, which is an improvement in cycle performance compared to the case for the non-coated PVdF membrane.
\end{abstract}

Keywords : PVdF membrane, Nano-composite coating, Lithium secondary batteries, Inorganic filler.

\section{Introduction}

Polymer electrolytes have some advantages over their liquid counter parts in the lithium rechargeable batteries. They have less possibility of internal short, leakage of electrolytes and flammability, and thereby enable the fabrication of the cell with a greater freedom of shape and size. ${ }^{1-3)}$

Even if many research progresses have been made on polymer electrolytes, ionic conductivity at room temperature and dimensional stability still remain an important issue to be addressed. ${ }^{3,4)}$ To enhance ionic conductivity and dimensional stability, the nano-sized inorganic fillers such as $\mathrm{LiAlO}_{2}, \mathrm{TiO}_{2}, \mathrm{SiO}_{2}$, $\mathrm{Al}_{2} \mathrm{O}_{3}$, and $\mathrm{CaCO}_{3}$, have been introduced with various techniques to polymer electrolytes. ${ }^{1,5-9)}$ However, they were not proven mechanically strong enough to withstand high tension required in cell manufacturing especially when the system is satisfied with higher ionic conductivity. Therefore, in most commercial applications,

*E-mail: jungpark@kaist.ac.kr polymer electrolytes based on polyolefin separator are now usually adopted to guarantee mechanical strength without sacrificing ionic conductivity.

In our previous work, we have proposed a new polymer electrolyte based on an alternative PVdF separator manufactured with modified phase inversion technique which can possibly replace the currently used polyolefin separator for lithium secondary batteries. We could already achieve high ionic conductivity of $0.85 \mathrm{mScm}^{-1}$ and mechanical strength of $126 \mathrm{MPa}$ at room temperature by controlling morphology of the PVdF membrane. ${ }^{10,11)}$ In the present study, we attempted to further enhance ionic conductivity of polymer electrolyte and cycle performance of the polymer-based unit cell with combinational approach on the basis of the alternative PVdF-based separator and inorganic filler.

\section{Experimental}

\subsection{Preparation of PVdF membrane}

The mixture of PVdF and DMF ( $1: 4$ in weight ratio) was heated at $70^{\circ} \mathrm{C}$ for $5 \mathrm{hrs}$ and then $5 \mathrm{wt} \%$ of distilled 
water was added to the solution with stirring for morphology control of the membrane. The solution containing distilled water was cast on a glass plate using a doctor blade with a gap of $20 \mu \mathrm{m}$ and dried in a dry oven at $90^{\circ} \mathrm{C}$ for $3 \mathrm{~min}$. The resulting PVdF membrane was directly immersed into a coagulation bath that is filled with non-solvent (deionized water) for $6 \mathrm{hrs}$ to generate pores. The porous PVdF membrane was finally stretched to $350 \%$ of the original length.

\subsection{Preparation of nano-composite PVdF} membrane

The nanosized-fumed silica (Cab-O-Sil EH5, Cabot Co.) was dissolved in $\mathrm{N}, \mathrm{N}$-dimethylformamide (DMF, Aldrich) with stirring. Then, $20 \mathrm{wt} \%$ of PVdF homopolymer (SOLEF6020, Solvay: weight average molecular weight 320,000 ) was added into the prepared silica solution and the mixed polymer solutions were heated at $70^{\circ} \mathrm{C}$ for $5 \mathrm{hrs}$. These mixed polymer solutions were cast on a glass plate using a doctor blade with a gap of $20 \mu \mathrm{m}$ and then dried in a dry oven at $90^{\circ} \mathrm{C}$ for $3 \mathrm{~min}$. The casted PVdF membranes were immersed into a coagulation bath which was filled with non-solvent (deionized water) for $6 \mathrm{hrs}$ to generate pores by phase inversion.

\subsection{Preparation of coated nano-composite PVdF} membrane

Firstly, the PVdF-HFP (KynarFlex 2801, Atofina Chemicals; 8 mol\% HFP) and an appropriate amount of inorganic filler were dissolved in acetone with a ratio (9.6 : 0.4 in weight ratio). Then, the stretched PVdF membranes were coated by dip coating method and dried in a dry oven at $50^{\circ} \mathrm{C}$ for $12 \mathrm{hrs}$ to remove residual solvent.

\subsection{Scanning electron microscope (SEM)}

The morphologies of the top and bottom surfaces of the membranes were observed using a low voltage field emission scanning electron microscope (FESEM, FEI, Sirion, Netherlands). For taking the cross sectional SEM images, the samples were obtained by fracturing in liquid nitrogen. Then, the sample was attached to a sample holder using conductive copper tapes and silver pastes were applied in order to enhance electronic conductivity.

\subsection{Tensile strength}

Tensile strength of the composite PVdF membrane was determined by using an Instron 5583 Tensile Tester. Polymer membrane was stretched uni-directionally as the clamps move apart from each other at a constant rate of $10 \mathrm{~mm} / \mathrm{min}$. The exact stretch ratio was determined by dividing the final length of the stretched portion of film by its initial length before stretching.

\subsection{Thermal analysis}

Thermal behaviors of the composite PVdF membranes were studied by using a differential scanning calorimeter (Dupont TA 2000 DSC). Each sample was loaded in hermetically sealed with aluminum pans and scanned at a heating rate of $10^{\circ} \mathrm{C} / \mathrm{min}$. over a temperature range of $25^{\circ} \mathrm{C}$ to $250^{\circ} \mathrm{C}$ under nitrogen atmosphere.

\subsection{Electrical measurements}

Both PVdF membrane and coated PVdF membrane were immersed into liquid electrolyte, $1 \mathrm{M} \mathrm{LiPF}_{6}$ salt in ethylene carbonate (EC)/diethyl carbonate (DEC)/ propylene carbonate (PC) [30/65/5, by vol.] (Cheil Industries, Korea), and they were sandwiched between the two stainless-steel (SS) electrodes. The ionic conductivities of the membranes were obtained from bulk resistance that was measured by a.c. complex impedance analysis using a Solartron 1255 Frequency Response Analyzer (FRA) over the frequency range of $100 \mathrm{~Hz}$ to $1 \mathrm{MHz}$. The prepared pouch type cell for cycle performance was made as follows: The anode electrode was made by using MCMB, conducting agent, PVdF binder, and copper current collector. The cathode electrode was made with $\mathrm{LiCoO}_{2}$, conducting agent, PVdF binder, and aluminum current collector. The charge/discharge test for the unit cell was carried out by galvanostatic charge/ discharge cycling tester (TOSCAT-3000, Toyo System Co.) at room temperature.

\section{Results and Discussion}

\subsection{Nano-composite PVdF membrane}

Cross sectional SEM morphologies of the composite PVdF membrane with inorganic filler are shown in Fig. 1. As shown in Fig. 1(a), the size of inorganic filler is approximately $15 \sim 25 \mathrm{~nm}$. The white circles of Fig. 1(b) correspond to inorganic fillers that are not dispersed uniformly in the porous PVdF membrane. Fig. 1(c) represents magnified SEM images of the white circle in Fig. 1(b). The local aggregation of inorganic filler is caused by a difficulty of dispersion in highly viscous PVdF polymer solution. 


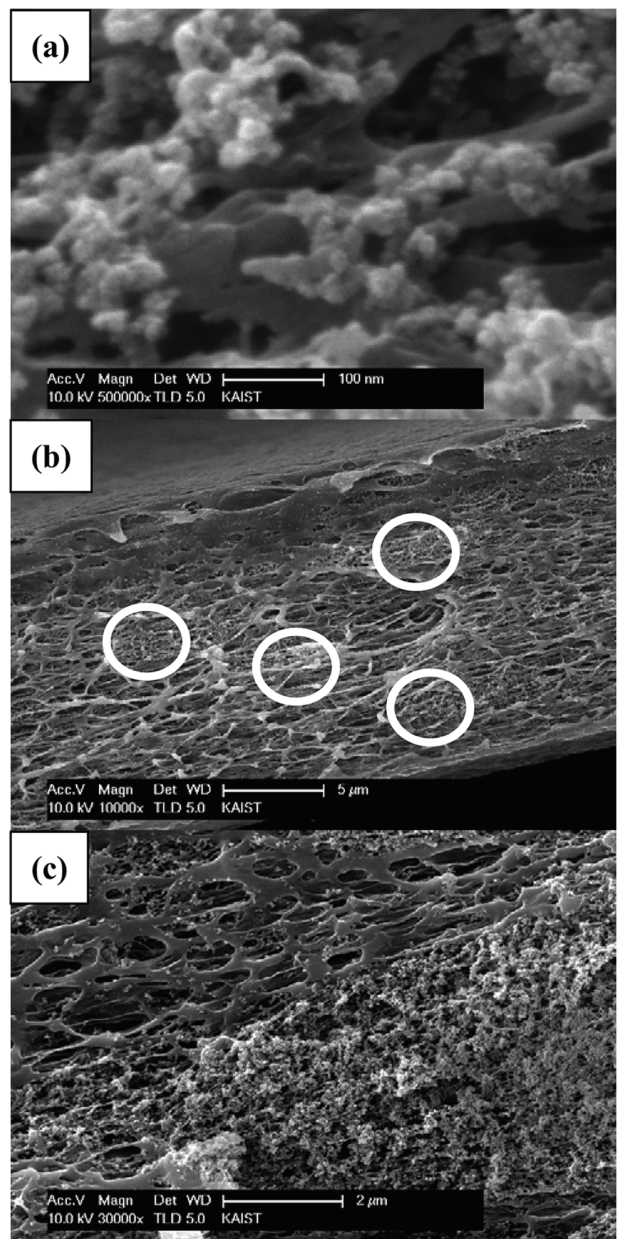

Fig. 1. Cross sectional SEM images of the composite PVdF membrane.

The mechanical strength of the PVdF composite membrane and stretched composite membrane are presented in Fig. 2 and Table 1. By uni-axial stretching, it is possible to open and extend pores of the membrane, which can lead to an increase in the uptake of electrolyte and also to an enhancement of crystallinity by chain orientation of the membrane accompanied by an increase of mechanical strength. ${ }^{10,11)}$ In our previous work, morphology-controlled PVdF membrane made

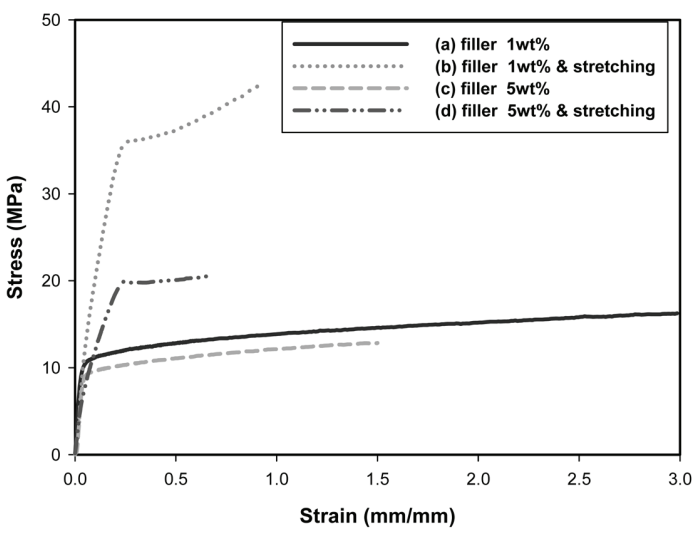

Fig. 2. Mechanical strength of the PVdF composite membrane: (a) PVdF membrane with $1 \mathrm{wt} \%$ of filler; (b) PVdF membrane with $1 \mathrm{wt} \%$ of filler and $200 \%$ stretching; (c) PVdF membrane with $5 \mathrm{wt} \%$ of filler; (d) PVdF membrane with $5 \mathrm{wt} \%$ of filler and $120 \%$ stretching.

by modified phase inversion technique could be stretched up to $350 \%$ and its tensile strength reached $126 \mathrm{MPa}$. In contrast, stretching ratio of the composite PVdF membrane with inorganic filler was reduced to $200 \%$ and its tensile strength sharply decayed to $42 \mathrm{MPa}$, which is believed due to non-uniform dispersion of inorganic filler in the composite membrane. With a further increase of inorganic filler content in composite membrane, the tensile strength was more significantly reduced, resulting in $23 \mathrm{MPa}$ after $120 \%$ of stretching. The change in crystallinity with content of inorganic filler, which is directly related to mechanical strength, can be evaluated from the heat of fusion of the membrane. Fig. 3 shows DSC thermograms of the composite membranes and it is observed that the heat of fusion ( $\ddot{\mathrm{H} H m}$ ) is decreased from $56.7 \mathrm{~J} / \mathrm{g}$ to $52.1 \mathrm{~J} / \mathrm{g}$ with addition of inorganic filler. This is because the inorganic fillers are not uniformly dispersed, which directly influences crystallinity of PVdF polymer chain.

\section{3-2 Coated composite PVdF membrane}

In order to achieve high ionic conductivity without sacrificing mechanical property of the composite

Table 1. The tensile strength and thickness of the composite PVdF membranes with uni-axial stretching

\begin{tabular}{lcccc}
\hline & Filler 1 wt \% & $\begin{array}{c}\text { Filler 1 wt } \% \\
\text { Stretching 200\% }\end{array}$ & Filler 5 wt \% & $\begin{array}{c}\text { Filler 5 wt \% } \\
\text { Stretching 120\% }\end{array}$ \\
\hline Tensile strength $(\mathrm{MPa})$ & 17 & 42 & 13 & 23 \\
Thickness $(\mu \mathrm{m})$ & 52 & 39 & 58 & 50 \\
\hline
\end{tabular}




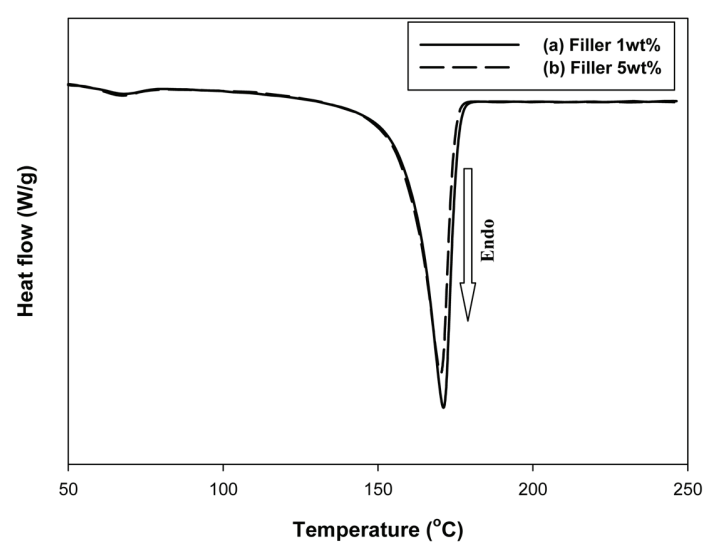

Fig. 3. DSC thermograms of the composite PVdF membranes; (a) composite PVdF membrane with $1 \mathrm{wt} \%$ of filler ratio, (b) composite PVdF membrane with $5 \mathrm{wt} \%$ of filler ratio.

membrane, the highly stretched PVdF membrane with $126 \mathrm{MPa}$ of tensile strength was used as a matrix for the membrane with a coating layer. The coating layer is the composite that is composed of PVdF-HFP copolymer and embedded inorganic filler. The schematic structure of the coated composite membrane is illustrated in Fig. 4. The expected advantages of the presence of coating layer with inorganic fillers on the surface of the stretched PVdF membrane are the increase of liquid electrolyte retention ability, adhesion between electrode and membrane, and enhancement of ionic conductivity owing to high uptake of liquid electrolyte induced by additional contact surface area with liquid electrolyte by incorporation of the dispersed inorganic fillers.

Fig. 5 shows ionic conductivities and uptake amounts of the coated and non-coated membranes. The coated composite membrane shows higher ionic conductivity $(1.03 \mathrm{mS} / \mathrm{cm})$ than the non-coated membrane $(0.85 \mathrm{mS} / \mathrm{cm})$. This is believed to come from high

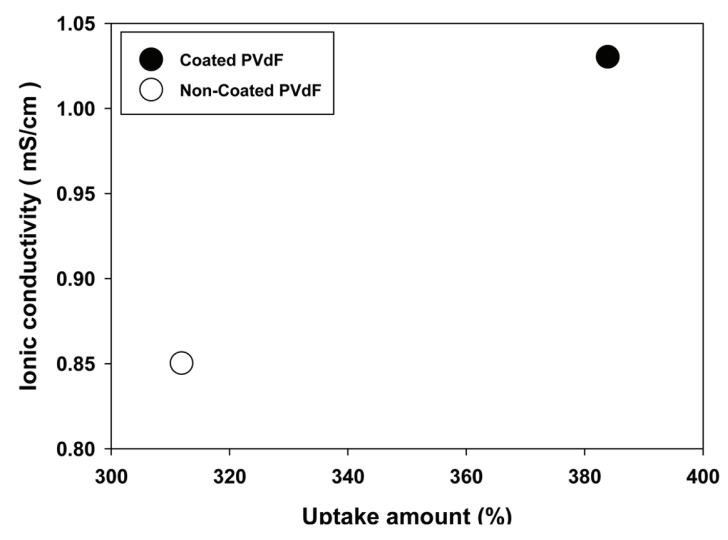

Fig. 5. The ionic conductivity and liquid electrolyte uptake amount of the composite coated and non-coated PVdF membrane.

uptake of liquid electrolytes derived from hydrophilic property and higher surface area of inorganic filler. (Size: $11 \mathrm{~nm}$, surface area $380 \mathrm{~m}^{2} / \mathrm{g}$ )

Fig. 6 shows the surface morphology of the noncoated and coated PVdF membranes. It is observed from Fig. 6(c) that network structure of the PVdF-HFP phase is formed at the surface of coating layer and inorganic filler is located inside the PVdF-HFP network structure. Fig. 7 shows the interfacial stability between the coating layer and PVdF membrane under the presence of liquid electrolyte. The coating layer was very stable even after immersion in liquid electrolyte for 3 days because of good compatibility between PVdF matrix membrane and PVdF-HFP matrix of coating layer.

In order to evaluate the electrochemical performance of a lithium ion cell using the coated PVdF membrane, we fabricated a graphite/coated composite PVdF membrane (EC/DEC/PC with $\left.1 \mathrm{M} \mathrm{LiPF}_{6}\right) / \mathrm{LiCoO}_{2}$ cell. The a.c. impedance spectroscopy was used to investigate the interfacial behavior between the matrix PVdF

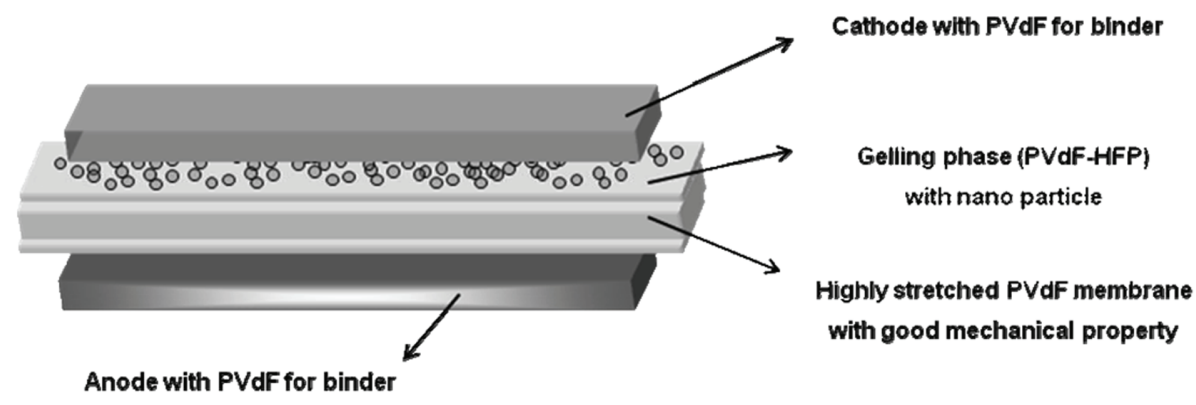

Fig. 4. Schematic structure of the unit cell with nano composite coated PVdF membrane. 

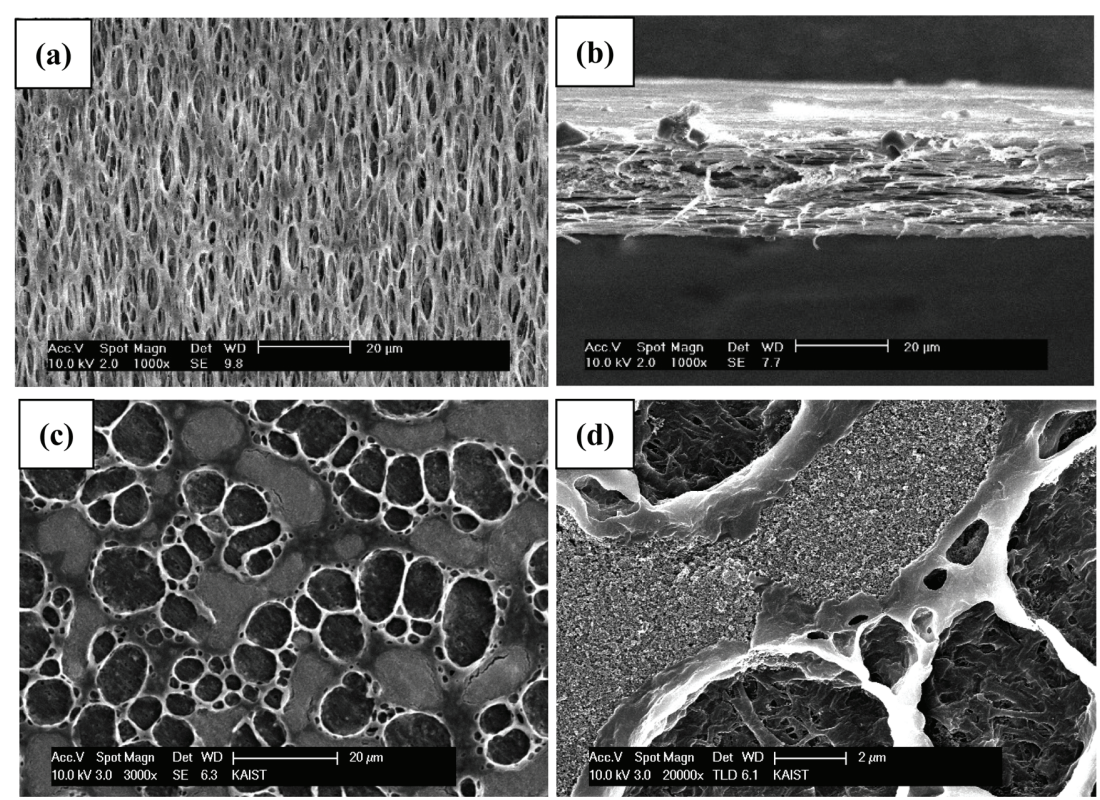

Fig. 6. Morphologies of the non-coated PVdF membranes ((a) top, (b) side), composite coated PVdF membranes; $1 \mathrm{wt} \%$ of filler was contained in composite coating layer $(\times 3,000$ for $(c), \times 20,000$ for (d)).
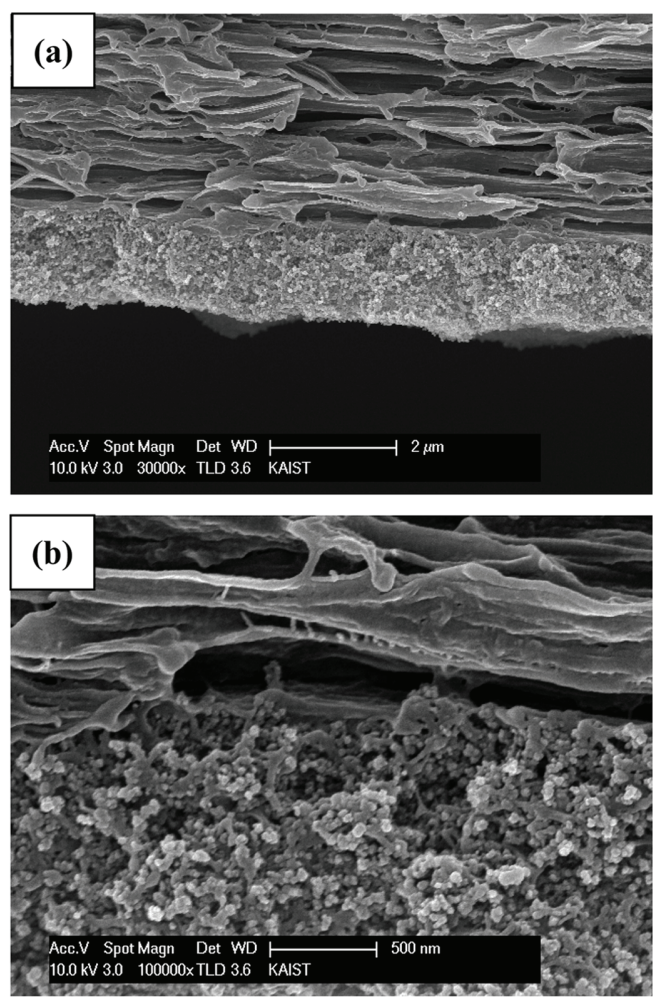

Fig. 7. Cross sectional SEM images of composite coated membrane after immersed in liquid electrolyte for 3 days. $(\times 30,000$ for $(a), \times 100,000$ for $(b))$.
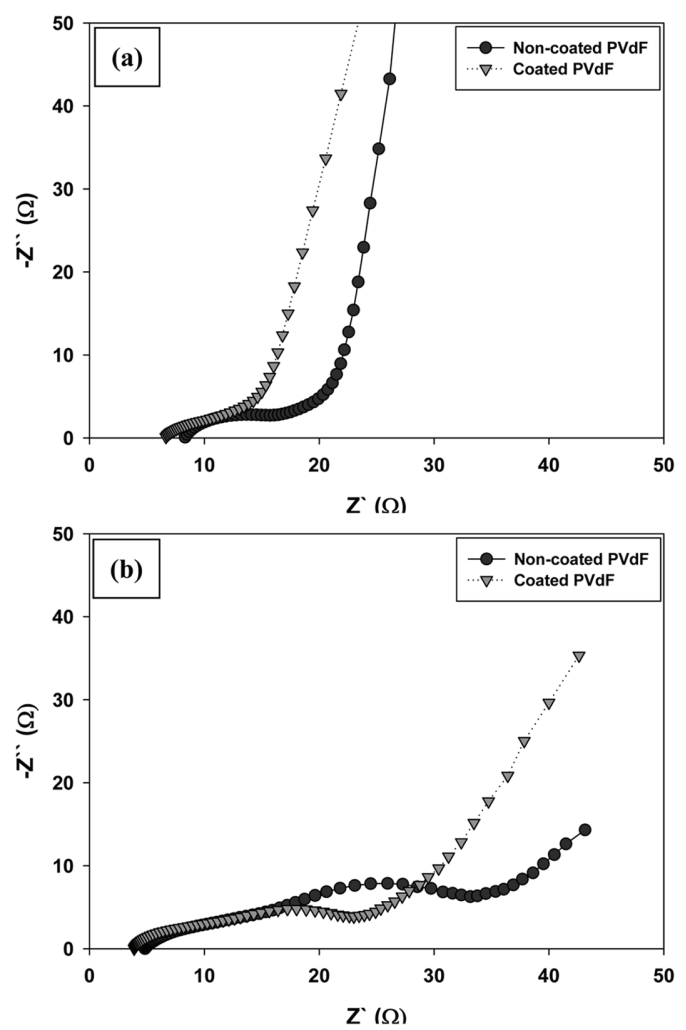

Fig. 8. The a.c. impedance spectra of the unit cell; (a) before precycling, (b) after precycling at $\mathrm{C} / 10$ rate. 
membrane and the coated PVdF layer. The low interfacial resistance of the electrode and membrane is also an important factor to guarantee high performance in rechargeable lithium batteries. Fig. 8(a) shows the a.c. impedance spectra of the unit cell in the initial state. The bulk resistance of the unit cell using the coated PVdF membrane was lower than that of the unit cell based on the non-coated PVdF membrane. It is attributed to higher uptake of liquid electrolyte and better adhesion property to electrode of the coating layer with more amorphous PVdF-HPF domains than the noncoated PVdF membrane. Fig 8(b) shows the a.c. impedance spectra of the unit cell after precycling at $\mathrm{C} / 10$ rate. The interfacial resistance of the coated membrane associated with the passivation layer is also shown lower than that of the non-coated membrane after precycling.

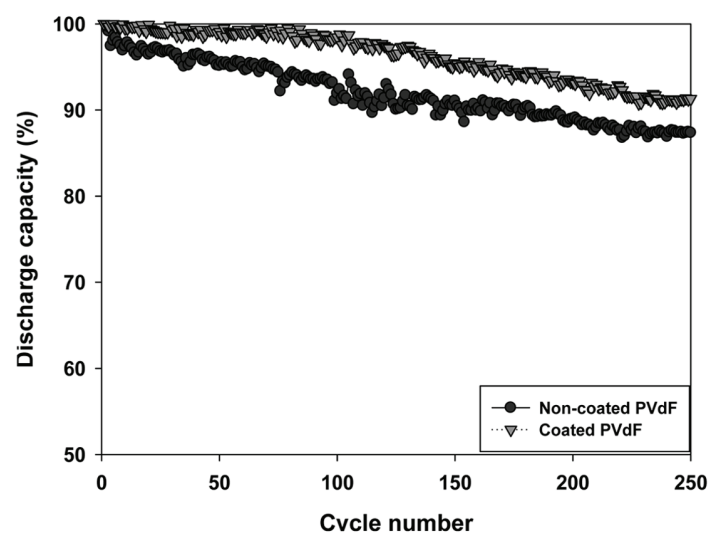

Fig. 9. Discharge capacity of the unit cell based on the non-coated PVdF membrane and the composite coated PVdF membrane.

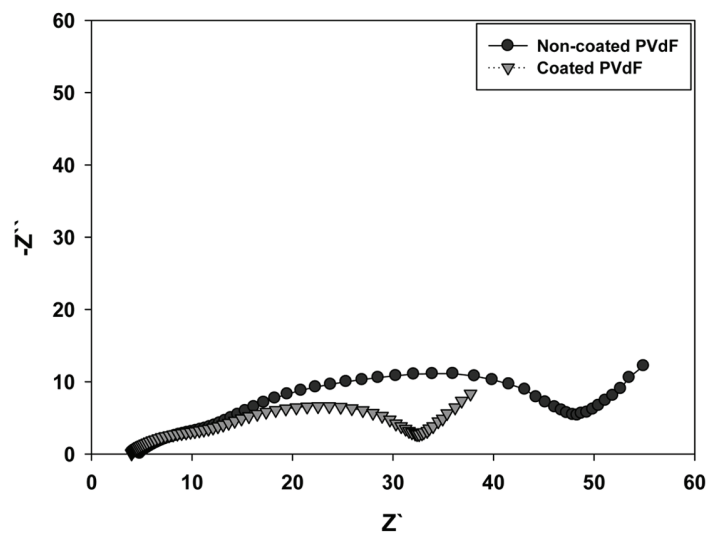

Fig. 10. The a.c. impedance spectra of the unit cell based on the non-coated PVdF membrane and the composite coated PVdF membrane after 250 cycles.
The low interfacial resistance of the unit cell based on the coated membrane was expected to result in higher capacity retention than the cell with non-coated membrane.

Cycling test of the unit cell was conducted in a voltage range of $3.0 \sim 4.2 \mathrm{~V}$ (constant current-constant voltage in charge and constant current in discharge) with at $\mathrm{C} / 2$ rate up to 250 cycles. The discharge capacity curves are shown in Fig. 9. The discharge capacity of the unit cell based on the coated PVdF membrane after 250 cycles is $91 \%$ of the initial discharge capacity whereas the unit cell based on the non-coated PVdF membrane shows $87 \%$ of the initial value after 250 cycles. The interfacial resistances after cycles are presented in Fig. 10. The coated membrane shows relatively stable interfacial resistance compared to the non-coated PVdF membrane after cycling, which is indicative of higher interfacial stability for the coated PVdF membrane compared with the non-coated PVdF membrane.

\section{Conclusions}

The porous composite PVdF membrane with inorganic filler was prepared by phase inversion method. In order to achieve high ionic conductivity and electrochemical performance without sacrificing mechanical property of the matrix membrane, coating layer was simply introduced to highly stretched PVdF membrane. The interfacial stability of the coated layer to electrode was good with immersion in the liquid electrolyte. The coated PVdF membrane showed enhanced ionic conductivity compared to the non-coated PVdF membrane, which seems to be due to high chemical affinity to liquid electrolyte and large surface area. The cell based on the coated PVdF membrane showed an improvement in cycle performance compared to the cell with non-coated $\mathrm{PVdF}$ membrane at $\mathrm{C} / 2$ rate after 250 cycles.

\section{Acknowledgement}

This research was supported by a grant from the $2^{\text {nd }}$ Brain Korea 21 project.

\section{References}

1. F. Croce, G. B. Appetecchi, L. Persi, and B. Scrosati, Nanocomposite polymer electrolytes for lithium batteries, Nature. 394, 456 (1998).

2. P. Arora and Z. Zhang, Battery separators, Chem. Rev. 104, 4419 (2004). 
3. A. Manuel Stephan, Review on gel polymer electrolytes for lithium batteries, Eur. Polym. J. 42, 21 (2006).

4. N. S. Choi and J. K. Park, New polymer electrolytes based on PVC/PMMA blend for plastic lithium-ion batteries, Electrochim. Acta, 46, 1453 (2001).

5. N. T. Kalyana Sundaram and A. Subramania, Nano-size $\mathrm{LiAlO}_{2}$ ceramic incorporated porous PVDF-co-HFP electrolyte for lithium-ion battery applications, Electrochim. Acta, 52, 4987 (2007).

6. K. M. Kim, N. G. Park, K. S. Ryu, and S. H. Chang, Characteristics of PVdF-HFP/TiO ${ }_{2}$ composite membrane electrolytes prepared by phase inversion and conventional casting methods, Electrochim. Acta, 51, 5636 (2006).

7. M. Wachtler, D. Ostrovskii, P. Jacobsson, and B. Scrosati, A study on $\mathrm{PVdF}$-based $\mathrm{SiO}_{2}$-containing composite gel-type polymer electrolytes for lithium batteries, Electrochim. Acta 50, 357 (2004).

8. A. S. Best, J. Adebahr, P. Jacobsson, D. R. MacFarlane, and M. Forsyth, Microscopic interaction in nanocomposite electrolytes, Macromolecules, 34, 4549 (2001).

9. S. S. Zhang, A review on the separators of liquid electrolyte Li-ion batteries, J. Power Sources, 164, 351 (2007).

10. W. H. Seol, Y. M. Lee, and J. K. Park, Preparation and characterization of new microporous stretched membrane for lithium rechargeable battery, J. Power Sources, 163, 247 (2006).

11. W. H. Seol, Y. M. Lee, J. K. Park, Enhancement of the mechanical properties of PVdF membranes by non-solvent aided morphology control, J. Power Sources, 170, 191 (2007). 